Annals of Plant Sciences

ISSN: 2287-688X

OPEN ACCESS

www.annalsofplantsciences.com

Review Article

\title{
Harmful effects of Parthenium hysterophorus and management through different approaches - A review
}

Jayaramaiah R. ${ }^{*}$, Balenahalii N. Ramesh ${ }^{2}$, Krishnaprasad B.T. ${ }^{2}$, Sunil Kumar R. ${ }^{2}$, Pramodh G. ${ }^{1}$, Ramkumar C. ${ }^{3}$, Sheshadri T. ${ }^{4}$

${ }^{1}$ Department of Agronomy, College of Agriculture, University of Agriculture Science, Bangalore, Karnataka, India.

${ }^{2}$ Department of Biotechnology, College of Agriculture, University of Agriculture Science, Bangalore, Karnataka, India.

${ }^{3}$ Department of Food Science and Technology, College of Agriculture, University of Agriculture Science, Karnataka, India.

${ }^{4}$ Director of Research, University of Agriculture Science, GKVK, Bangalore, Karnataka- 560065, India.

Received: February 30, 2017; Accepted: March 21, 2017

\begin{abstract}
Parthenium bysterophorus is commonly known as congress grass or carrot weed in India. It belongs to Asteraceae family and native to subtropics of North and South America. It is an invasive plant species that disturbs cultivated areas, roadside vegetation, gardens etc. $P$. hysterophorus is considered as one of the worst weeds responsible for causing health problems in animals and humans viz., dermatitis, asthma and bronchitis besides loss to agriculture and ecosystem. Nowadays, it has become one of the major weeds in almost all types of agricultural lands and other areas. Many control methods ranging from preventive, physical methods by manual uprooting, burning and allelopathic management through competitive plants like Cassia tora, Cassia uniflora and Cassia sericea, have been recommended for management of P. hysterophorus. Likewise, insect Zygogramma bicolorata has proven successful in managing P. hysterophorus. Further, microorganisms like Alternaria alternata, Scerotiia sclerotiorum, Fusarium Pallidoroseum, Ralstonia solanacearum, and Xanthomanas campestris are reported to infest $P$. hysterophorus. Use of chemical herbicides mainly glyphosate@2.5 kg a.i. ha-1, atrazine@2.6 kg a.i.ha-1,2,4-D amine@ @ l/ ha-1, Paraquat $0.5 \mathrm{l} / \mathrm{ha}^{-1}$ were proved effective in managing P. hysterophorus. No single option is suitable to control this invasive weed. Successful control of this weed can only be achieved by an integrated weed management approaches.
\end{abstract}

Key words: Parthenium hysterophorus; Biological control; Integrated approach; Preventive measures; Allelopathic control.

\section{Introduction}

Weeds are plants that are unwanted in a given situation and may be harmful, dangerous or economically detrimental. Weeds are a serious threat to primary production and biodiversity. They reduce farm and forest productivity, $P$. bysterophorus dominate over the native species and adversely affect the biodiversity. Therefore, weed management in agricultural ecosystems is one of the most key operations (Yadollahi et al., 2014). P. bysterophorus is a flowering plant which belongs to Asteraceae family. It is an aggressive, ubiquitous, annual, herbaceous weed with no economic importance unravelled till now. It is an erect and much branched annual or ephemeral herb, known for its notorious role as environmental, medical, and agricultural hazards (Kaur et al., 2014). It is native to the American tropics, common name includes Congress grass, Congress weed, Santa Maria, Bitter weed, Carrot grass, False ragweed, Fever few, White top, the "Scourge of India". This flower head (capitulum) is surrounded by bracts (modified leaves) that form an involucre beneath or around a flower cluster (Warshaw and Zug, 1996). It is profusely branched, leafy herb resembling a bush or shrub because of its height (1-2.5m). The stem becomes tough and woody as the plant matures into a hardy bush. It can produce $\sim 624$ million pollen grains per plant and carried to spread to other areas by wind. It is an extremely prolific seed producer with upto 25,000 seeds (achenes) per plant. The plant is photo-thermo insensitive hence, it grows round the year except in severe winters. It grows in almost all types of soil except near the seashore as the saline soil is not conducive to $P$. bysterophorus flowering (Chembolli and Srinivas, 2007).

*Corresponding Author:

Dr. Jayaramaiah R.,

Associate Professor,

Department of Agronomy, College of Agriculture,

UAS, Bangalore, Hassan, Karnataka, India.

E-mail: jayaram.uas@gmail.com
It is an annual herb that was accidentally introduced into India in the year 1956 through contaminated wheat shipments from the USA (Lonkar et al., 1974). It is the leading cause of plant induced airborne contact dermatitis in India. This plant has infested most of rural and urban areas and causing epidemics of dermatitis. It also showed serious impact on human health, animal husbandry, crop production and biodiversity (Chembolli and Srinivas, 2007; Mitchell and Calnan, 1978). It contains allergenic sesquiterpene lactones (SQLs). The SQLs are found in the leaves, stems, flowers, and some pollen. The highest concentrations are found in trichomes which are present on stems, the underside of leaves and in the flowering heads. Several thousands of cases of allergic contact dermatitis and also some fatalities have been reported (Lonkar et al., 1974; Mitchell and Calnan, 1978). After 10 years of exposure to the weed, $10-20 \%$ of the population will develop severe allergic reactions. There may be hay fever, asthma; dermatitis caused by dust, debris as well as pollen from the plant. The severity of dermatitis in India is greater because the plant grows more vigorously in India and contains large amounts of the sesquiterpene lactone and parthenin, which is absent in P. bysterophorus that grows in South America (Chembolli and Srinivas, 2007; Mcfadyen, 1995). The current review emphasizes the problem associated with $P$. bysterophorus as a weed and the effective control measures.

Harmful effects of Parthenium hysterophorus on Agriculture and Ecosystem

The $P$. hysterophorus weed has infested about 35 million hectares of land in India (Sushilkumar, 2009). P. bysterophorus plant contains chemicals, like parthenin,

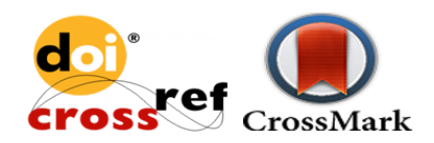


hysterin, hymenin, and ambrosin, and due to the presence of these chemicals, the weed exerts strong allelopathic effects on different crops (Gunaseelan, 1998). The weed affects nodulation in legumes due to inhibition of activity of nitrogen fixing and nitrifying bacteria, namely, Rhizobium, Actinomycetes, Azotobacter, and Azospirillum. P. hysterophorus produces enormous numbers of pollens (on an average 624 million/plant), which are carried away at least to short distance in clusters of 600800 grains, and settles on the vegetative and floral parts, including stigmatic surface, inhibiting fruit setting in crops like tomato, brinjal, beans, capsicum, and maize. In India, P. hysterophorus causes a yield decline of up to $40 \%$ in agricultural crops (Khosla and Sobti, 1981).

P. hysterophorus has the potential to disrupt the natural ecosystems. It causes a total habitat change in native Australian grasslands, river banks, open woodlands and flood plains (Chembolli and Srinivas, 2007). This weed can rapidly invade into new surroundings often it can replace the native indigenous species and pose a serious threat to biodiversity (Seema Patel, 2011). It is an aggressive colonizer of roadsides, wasteland, railway sides, water courses, and cultivated fields. It is reported that $P$. bysterophorus occupied 14.25 million hectares of farm land during 2001-2007, when compared to 2 million hectares in 1991-2000 (Javaid and Adrees, 2009). A broad survey conducted in Bangladesh on invasive alien species and their presence indicate that $P$. hysterophorus can establish on different land types viz., road side, homestead, low land, fallow land and railway track. They reported that $P$. bysterophorus have ability to adapt to new habitats and thereby reducing the number of indigenous species (Akter and Zuberi, 2009). In Ethiopia, P. bysterophorus is reported to cause sorghum grain yield losses between $40-97 \%$ if it is left uncontrolled throughout the season (Tamado et al., 2002; Aneja 1999). P. hysterophorus infests about 170000 $\mathrm{km}^{2}$ of prime grazing country in Queensland, causing loss of around 16.8 million dollar per year to the pasture industry in Australia (Chippendale and Panetta, 1994). Also, it was reported that $P$. hysterophorus was estimated to reduce the carrying capacity of affected farms on cracking clay soil with an annual rainfall of 600 and $800 \mathrm{~mm}$ (Fessehaie et al., 2005; Mcconnachie et al., 2011).

$P$. hysterophorus known to cause severe detrimental effect on mankind by causing many skin and respiratory disorders. The main classical dermatitis also known as air borne contact dermatitis (ABCD) which affects the face, eyelids, neck, chest and popliteal fossae (Warshaw and Zug, 1996). The second major is chronic actinic dermatitis (CAD) which involves the exposed areas mainly forehead, cheeks, nape of neck, rim of ears, forearm and hands and under surface of chin and depth of the skin folds (Tamado et al., 2002). The other skin problems include is mixed pattern combining of ABCD and CAD which shows as scattered infiltrated scaly papules over the exposed parts and dermatitis over eyelids, flexures of extremities on neck. The fourth one is photosensitive lichenoid eruption pattern which presents with violaceous papules, and plaques over sun exposed parts such as cheek, forehead, ears, upperchest and back, dorsae of hands (Kaur et al., 2014). The prurigo nodularis like pattern present as multiple hyperkeratotic papules and nodules with characteristic histopathologic features similar to prurigo nodularis [Kaur et al., 2014; Sharma et al., 2013; Aneja, 1991). Akthar et al. Showed P. bysterophorus extracts responded with positive skin reaction to $\mathrm{mAb} 2$ and also involvement of TH type cytokines in $P$. bysterophorus dermatitis (Akhtar et al., 2010), shown in figure 1.

The P. hysterophorus also acts as a collateral host for many diseases caused by viruses in crop plants. It has showed harmful effects to animals causing dermatitis with pronounced skin lesions on various animals including horses and cattles. If eaten, it is responsible for mouth ulcers with excessive salivation. Significant amount (10$50 \%$ ) of this weed in the diet can kill cattle (Narasimhan et al., 1977). In addition, it causes anorexia, pruritus, alopecia, diarrhea, and eye irritation in dogs besides causing acute illness. When grazing animals fed on grass mixed with $P$. hysterophorus yield bitter milk and tainted meat from buffaloes, cows and goats (Aneja, 1991). The $P$. hysterophorus extract when fed to rat results in significant reduction of rat WBC count which suggests it can weaken immune system.

\section{Management of Parthenium hysterophorus}

Various methods, viz., preventive, physical, cultural, chemical, bio herbicidal, and integrated approaches are being practiced to manage this weed around the globe. Singh et al. 2004 considered that use of bio prospecting tools like using insects, microorganisms and competitive plants are the most economic way of managing $P$. hysterophorus (Singh et al., 2004). The new concept emerging in the use of botanical extracts which can affect germination and growth of $P$. bysterophorus. Studies are also attempted to extract the active ingredient responsible for weed controlling property of botanicals (Sushilkumar and Saraswat, 2001).

\section{Preventive measures for management of Parthenium hysterophorus}

It encompasses all measures taken to prevent the introduction and/or establishment and spread of weeds in local, regional or national level. No weed control programme is successful if adequate preventive measures are not taken to reduce weed infestation. Preventive control measures viz., clean cultivation, use of $P$. bysterophorus weed free clean and certified seeds, keeping seed beds free from weed, avoid feeding the material containing $P$. hysterophorus seeds to the farm animals, avoid adding the $P$. hysterophorus which has already set seeds to the manure pits, clean the farm machinery thoroughly before use, keep irrigation channels free from $P$. bysterophorus, fence-lines, and un-cropped areas clean, use vigilance and prevention by weed Laws play a pivotal role in avoiding the entry of $P$. hysterophorus.

\section{Physical and cultural Management}

Physical management involves intercultural operations coupled with hand weeding, a time consuming and unpleasant job, made worse by the health hazards involved with handling P. hysterophorus weed. Burning, another strategy employed to manage weed, is not a useful control strategy for $P$. bysterophorus. Burning destroys all other economically important plants growing in its vicinity. Manual uprooting of $P$. hysterophorus before flowering is the most effective method. Uprooting the weed after seed setting will increase the area of infestation. Several cultural practices like thorough land preparation, use of crops and varieties which have smothering effect, maintaining optimum plant population, crop rotation, mulching, soil solarisation, stale seed bed technique and proper fertilizer and water 
management are important in controlling this weed [Ray and Gour, 2012; Javaid, 2007).

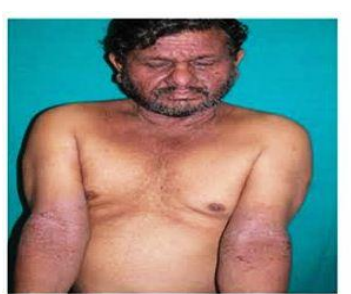

a

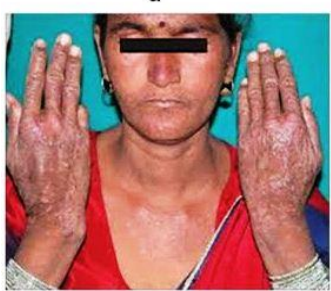

c

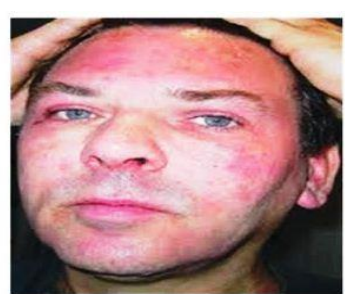

b

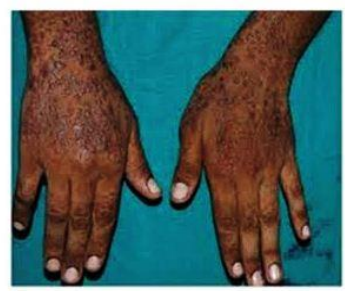

Figure 1. Common symptoms of commonly known $P$. bysterophorus dermatitis, (a, b) Airborne contact dermatitis (ABCD); (c) Chronic actinic dermatitis in a female; (d) Prurigo like lesions over dorsa of hands.

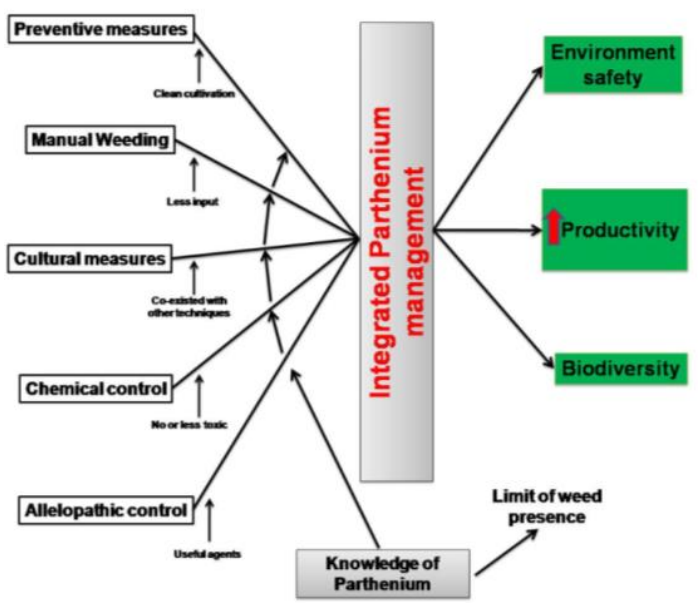

Figure 2. Schematic representation of integrated parthenium management

\section{Biological control of Parthenium hysterophorus} Biological control is an effective and environmentally sound method of mitigating the pests and their effects through the use of natural enemies. This method does not involve in the complete eradication of the unwanted organism. But it maintains its population lower than its average that would occur in the absence of bio control agents. In the last three to four decades a great interest has been given to manage $P$. bysterophorus by many biocontrol ages [Ray and Gour, 2012; Watson and Wymore, 1990). Many biocontrol agents like insects, fungi, nematodes, slugs, botanicals and microorganisms are used for controlling P. hysterophorus (Sushilkumar, 2009). Of the various biocontrol agents, control of weeds by using plant pathogens has gained acceptance as a safe, practical and environmentally beneficial method (Aneja, 2009).

Several insects have been tried to manage $P$. hysterophorus in different countries. In India, several insects have been reported on $P$. hysterophorus weed control but none of the insect has been found to be host specific yet. The classical approach was started by Jayanth in 1987 from Mexico with the introduction of host specific leaf feeding Zygogramma bicolorata pallister (Coleoptera: Chrysomelidae) and the stem galling moth Epiblema strenuana. These two insects have showed good potential to manage this weed (Jayanth, 1987). Both adult and larvae of Zygogramma bicolorata feed on leaves. In early stage, larvae feed on the auxillary and on the terminal buds and move on to the leaf blades as they grow and the fully-grown larvae enter the soil and pupate. The density of insect's one adult per plant caused skeletonization of leaves within 4-8 weeks. But, little successful was made due to very high germination of weed and moreover the insect is not a host specific and found that this insect can attack to other crops like sunflower in India (Dhileepan, 2001). The other insects such as stem borer, Scolytid beetle and Hypothenamus erudisus caused damage to the P. hysterophorus. Also, cerembycid borer Oberea sp. was able to significantly kill this weed (Kumar, 1979). Earias sp. also uses $P$. bysterophorus as an alternate host (Thontadarya and Hiremath, 1978). Also, Common tailed mealy bug Ferrisia virgate (Char et al., 1975) and mite Tetranychus cucurbitae and Tetranychus sp. and insects Aphis fabae and Pseudococcus sp. were reported to feed on Parthenium (Rajulu et al., 1976; Puttaswamy et al., 1976). Kumar et al. (1979) conducted survey and it indicates that Bug Leptocentrus taurus and scale insect Ortheria insignis feeds on Parthenium [Kumar et al., 1979; Thangavelu, 1980; Srikanth et al., 1988). Several other insects such as mealy bugs, Aphidoidea, Heliothis, belicoverpa, Clania cramari, Dicrasia obliqua and grass-hoppers have been reported feeding on $P$. bysterophorus (Sushilkumar, 2009). Many indigenous insects also play an important role in exotic weed suppression. Several other insects like Ferrisia virgata, Heliothis helicoverpa, Aphidoidea, Clania cramari, Dicrasia oblique and Caelifera reported on feeding P. bysterophorus. A cerembycid borer Nupserha sp. has been found infesting $P$. hysterophorus at Jabalpur and Vindhyanagar (M.P) (Sushilkumar, 1998). Insects like Zygograma bicolorata, Bucculatrix parthenica, Stobaera concinna, Epiblema strenuana, Carmentia ithacae, Conotrachelus albocinereus, Listronotus setosipennis, Smicronyx lutulentus, Platphalonidia mystica, are known to act as biocontrol agents on different parts of $P$. bysterophorus [Griffiths and Mcfadyen, 1993).

Microorganisms like fungus, bacteria and viruses are used as biological agents (Sushilkumar, 2009). The biological agents produce toxins which may kill or control the weeds are known as bioherbicides. The toxins produced by the fungi are called mycoherbicides. The fungi is obligate parasites on $P$. hysterophorus which causes rust are the first option because they exhibit narrow host ranges, higher reproducible capacities and efficient aerial dispersal (Evans and Ellison, 1990). The results of the study show that about 26 species of fungi were effective in controlling $P$. bysterophorus. Among them the main promising fungi are Puccinia abrupt var. partheniicola (Jackson) Parmelee, Puccinia xanthii var parthenii-hysterophorae (previously known as P. melampodii Diet. and Holw) (Uredinales), Entyloma compositarum De Bary (Ustilaginales) and Plasmopara halstedii (Farlow) Berl. and De Toni (Peronosporales). Of these Puccinia abrupta var. partheniicola and Puccinia xanthii var. Partheni bysterophorae from Mexico are the most potential classical bio control pathogen of $P$. bysterophorus (Kaur et al., 2014).

Many fungi have been reported to attack $P$. hysterophorus. Leaf spot disease on $P$. hysterophorus was caused by Colletotrichum gleosporioides (Kumar and Rao, 1977). The 
herbicide prepared from Alternaria alternate was found to be effective against seedling of $P$. hysterophorus [Rao and Rao, 1987; Deshpande et al., 1982). Pandey et al. 1996 showed that Sclerotium rolfsii capable of controlling the weed and increased the mortality rate of $P$. bysterophorus seedlings upto $90-95 \%$ and $35-40 \%$ in greenhouse and field trials respectively [Pandey et al., 1996; 1998). The root rot fungus Rhizoctonia solani are capable of infecting few $P$. hysterophorus plants in North Arcot district (Kumar et al., 1979). A survey conducted in Coimbatore reveals that 21-pathogenic species of Lasidiplodia theobromee cause blight and damage P. bysterophorus when it is 15-30 days' stage. Also, another Oidium partheni cause severe damage to $P$. bysterophorus at flowering stage (Jeyalakshmi et al., 2005). About 25 species of fungi were isolated from different places of Jabalpur, Madhya Pradesh and these include species of Alternaria alternate, Cladosporium, Acremonium, Colletotrichum, Drechslera, Phoma, Myrothecium, Curvularia, which cause leaf spot disease and species of Rhiropus, Chaetomium, Aspergillus (Rajak et al., 1990). Nineteen species of fungi are able to cause severe damage to the $P$. hysterophorus under laboratory trials which include A. alternate, A. dianthi, C. gleosporioides, A. macrosporus, Fusarium oxysporum, Phoma herbamm and Bipolaris, F. nioniliforme, Myrothecium roridum, sp. (Pandey et al., 1991). Two more fungi namely Fusarium oxysporum and Rhizoctonia solani were found to be highly potential causing severe damage to the weed in lab trial (Pandey et al., 1991). The sprays of Scerotiia sclerotiorum (200 g mycelium/litre water) showed reduction in the vigour of P. hysterophorus. Spore suspension of $10^{7}$ spores $/ \mathrm{ml}$ in water reduced the number of branches, height, flowers and plant growth in of $P$. hysterophorus when sprayed for a period of 30 days (Sushilkumar, 2009). F. Pallidoroseum and Alternaria alternate are capable of reducing seed germination, height, branches, leaves, and flowers considered to be an effective biocontrol agent against $P$. bysterophorus (Kauraw et al., 1997; Bhan et al., 1998). Out of 16 species of fungus that belongs to root zone of $P$. hysterophorus Alternaria alternate occurred most frequently and caused leaf spot disease (Dhawan and Gupta, 1997). The above references infer that there are no weed specific fungi which can infect and control P. hysterophorus.

Ralstonia solanacearum and Xanthomanas campestris bacteria are being used as biological agent to manage $P$. bysterophorus (Kishun and Chad, 1988). Mainly tobacco streak virus was found to infest $P$. hysterophorus and the insects mainly thrip species have been found to be transmitting the diseases from $P$. bysterophorus to sunflower, tobacco, soyabean, groundnut, black gram, cotton etc (Sushilkumar, 2009). Another virus namely tomato leaf curl virus has been found to be capable of infesting $P$. bysterophorus naturally. This virus can be transmitted by sucking insects of tobacco whitefly Bemisia tabaci (Devaraja et al., 2005). Phytoplasma type organism cause disease like phyllody, pear decline, aster yellow, potato witch broom, $P$. hysterophorus phyllody. These are obligatory pathogen which need host for their survival (Singh and Singh, 1998). Aster yellow disease caused by phytoplasma in P. hysterophorus and this was confirmed by direct and nested PCR using 16srRNA specific gene of phytoplasma (Raj et al., 2002).

Management of Parthenium hysterophorus through plants and allelopathy

Biological control of $P$. hysterophorus can be achieved by conserving naturally occurring plant species or purposeful use of known competitive plant species to manage or control $P$. bysterophorus. The allelochemicals like aresenoides, flavonoids, pentanoids and terpenoids can be used as herbicides, insecticides, nematicides, fungicides and growth regulators. These allelochemicals can be used as defence mechanism against herbivorous predators (Datta and Saxena, 2001). Number of plants has been reported to have allelopathic potential and efforts have been made to use them in controlling weed (Knox, 2008). Economical replacement of $P$. hysterophorus weed can be achieved by planting many plants like C. tora, C. sericea, $C$. uniflora, C. auriculata, Mirabilis jalapa, Sida spinosa, Amaranthus spinosus, Croton bonplandianum, Tephrosia purpurea, Hyptis suaveolens etc. which are able to suppress the P. hysterophorus in natural habitats (Wahab, 2005). Swati Vitonde et al. (2014) reported that extracts of $C$. uniflora and $C$. tora have an allelopathic potential which can act as herbicide to another weed such as $P$. bysterophorus (Vitonde et al., 2014). One more study showed that extracts of Imperata cylindrical, Otcantium annulatum, Desmostachya bipinnata and Sorgbum balepense significantly suppressed the seedling and germination growth of P. hysterophorus (Javaid et al., 2005). Kandasamy and sankaran from India showed that Cassia sericea able to reduce the accumulation of Parthenium population by $70 \%$ (Kandasamy and Sankaran, 1997). Plant parts like root and shoot extracts of Dicanthium annulatum, Sorghum balepense showed reduction in germination and early seedling growth of parthenium. Extracts of Azadirachta indica, Aegle marmelos and Eucalpptus tereticomis have inhibited the germination of P. bysterophorus weed (Kaur et al., 2014).

In India for the first time in 1966 reported that wastelands weed Xanthium strumarium capable to compete with P. bysterophorus (Maheshwari, 1966). C. sericea have potential to suppress $P$. hysterophorus. The $P$. hysterophorus when it was grown along with $C$. sericea having a weak growth and low dry weight when compared to $P$. bysterophorus when grown alone [Singh, 1983; Sushilkumar, 2009). The aqueous shoot extracts of $C$. occidentalis have significant effect against $P$. bysterophorus and proved promising alternative tool to manage (Jai et al., 2010). Survey conducted in Maharashtra found that Plant like $C$. tora, Hyptis suavelones, Xanthium strumarium, Tephrosia purpurea were found to compete with P. hysterophorus weed (Sarkate and Pawar, 2005; Gaikwad et al., 2008). Khan et al. (2010) reported that selected pasture species mainly buffel grass, purple pigeon grass, butterfly pea, kangaroo grass and bull Mitchell grass are found to replace $P$. bysterophorus weed in the infested region. The foliar spray of aqueous and methanol extracts of leaf $W$. Somnifera at different concentrations and found that it can inhibit the growth of noxious weed P. hysterophorus [Khan et al., 2010; Javaid et al., 2011).

The leaf leachets of Amaranthus viridis found to have potential to inhibit the growth of $P$. bysterophorus (Thapar and Singh, 2003), and the aqueous extracts obtained from leaf, stem and root of A. Spinosus found to have strong inhibitory effects on germination and growth of $P$. bysterophorus confirmed by bioassay and biochemical techniques (Swain et al., 2004). The C. uniflora is the strong growth inhibitor of $P$. hysterophorus. The study involving introduction of $C$. uniflora to a heavily infested $P$. hysterophorus area for 5 years reduced $P$. hysterophorus to 84\% (Joshi and Mahadevappa, 1986; Masum et al., 2013). In Australia O'Donnell and Adkins (2005) reported plant 
species mainly Bothriochloa inschupta (blue grass), Cenchrus ciliaris (bafel grass), Decanthim aristatum (floren blue grass), and Clitorea ternatea (butterfly pea grass) found to be effective in inhibiting the growth of $P$. hysterophorus. Plant species like Imperata cylindrica, Sorghum balepense and Cenchrus pennisetiformis from Pakistan (Javaid et al., 2005; Shabbir and Bajwa, 2005), and Eragrostis curvula, Digitaria eriantha and Panicum maximum from South Africa have been reported to compete with the P. hysterophorus (Van Der Laan et al., 2008).

\section{Chemical Management}

Chemical management is widely practiced to control $P$. bysterophorus in the areas where its natural enemies are not present. Use of many chemical herbicides, such as glyphosate@2.5 kg a.i.ha ${ }^{-1}$, atrazine@2.6 kg a.i.ha ${ }^{-1}$, bromoxynil@0.56 kg a.i.ha ${ }^{-1}$,common salt@20\%,2,4D amine@ @ l/ ha-1, 2,4-D ester @ 4 l/ ha-1, Floumeturon@2.24 kg a.i.ha-1, Hexazinone@3.5 kg a.i.ha ${ }^{-1}$, Metribuzin@0.7 kg a.i.ha-1, Norflurazon@2.24 $\mathrm{kg}$ a.i.ha ${ }^{-1}$ and Paraquat $0.5 \mathrm{l} / \mathrm{ha}^{-1}$ were known to be very effective in controlling this weed [Kathiresan et al., 2005; Ramamoorthy et al., 2004; Anonymous, 2011; Reddy et al., 2007; Singh et al., 2003; Mishra and Bhan, 1994). The application of 2,4-D EE (0.2\%) and metribuzin (0.25 and $0.50 \%$ ) were found to be more effective for controlling $P$. hysterophorus, causing complete elimination of parthenium species, and did not allow any emergence of weed. The stage and time of the rosette stage is the right time to apply post emergent herbicides in wasteland, noncropped areas, along railway tracks, water channels, and roadsides (Khan et al., 2012). Very effective treatments for $P$. bysterophorus weed control were glyphosate and metribuzin, having higher mortality at 4 weeks after treatment at both rosette and bolted stages than 2, 4-D, triasulfuron + terbutryn, bromoxynil $+\mathrm{MCPA}$ and atrazine $+\mathrm{s}$-metolachlor, atrazine, s-metolachlor. One of the easiest ways to manage $P$. hysterophorus is spraying a solution of common salt at $15-20 \%$ in non- cropped areas, open wasteland, railway tracks and road sides (CRC, 2003). Herbicide use in cropping areas is risky and found to have adverse effect on agriculture crops. Controlling $P$. hysterophorus in cropping areas can be done by selective herbicide use and by crop rotation. There are many herbicides available in the market to control $P$. bysterophorus.

Integrated management of Parthenium hysterophorus

Any single method for weed management mayn't be effective in controlling $P$. bysterophorus. Integration of different methods like preventive measures, mechanical, cultural, biological and chemical means keep the weeds under check at an economic threshold level. Integrated parthenium management uses a variety of technologies in a single weed management with the objective to increase the productivity of crop at a minimum cost taking in to consideration ecological and socio-economic constraints under a given agro-ecosystem (Fig 2).

\section{Conclusion and future prospects}

The management or control strategies are not successful because of its high regeneration capacity, high seed production ability and high germination ability throughout the year and more resistance to many chemical herbicides and also high adaptability in wide range of ecosystem. This noxious weed can be managed by public awareness and participatory integrated approaches. There is a need to encourage the research on utilization of this weed for insecticidal properties and try to evaluate the potential on pests of different crops. So far only fewer efforts have been made to control $P$. bysterophorus by using bio herbicides. More intense research in this direction is vital in the development of bioherbicides. Also, more efforts need to be done by agriculturists, scientists and government to work together for managing this troublesome weed through integrated and eco-friendly approaches.

\section{Acknowledgement}

Authors thanks to Dean, College of Agriculture, University of Agriculture Sciences, Hassan for his support. This work is funded by University of Agriculture Sciences, GKVK, Bangalore, India. Also, Startup grant for Young scientists by Science and Engineering Research Board, Department of Science and Technology, New Delhi, India.

\section{References}

1. Akhtar N, Satyam A, Anand V, Verma KK, Khatri R, Sharma A. Dysregulation of $\mathrm{TH}$ type cytokines in the patients of Parthenium hysterophorus induced contact dermatitis Clin Chim Acta, 2010, 411, 2024-2028.

2. Akter A, Zuberi MI. Invasive alien species in Northern Bangladesh: identification, inventory and impacts. Int J Biodivers Conserv, 2009, 15, 129-134.

3. Aneja KR. Biotechnology for the production and enhancemen of mycoherbicide potential. In: From Ethnomycology to Fungal Biotechnology Plenum, London, UK, 1999, 91-114.

4. Aneja KR. Biotechnology: an alternative novel strategy in agriculture to control weeds resistant to conventional herbicides. In: Antimicrobial Resistance from Emerging Threats to Reality, Narosa Publishing House, New Delhi, 2009, 160-173.

5. Aneja KR. Deadly weed Parthenium hysterophorus and its controla review. In: Aery NC, Chaudary BL (eds) Botanical researches in India. Himanshu Publications, Udaipur, India, 1991, 258 269.

6. ANONYMOUS) Registered herbicides used for Parthenium bysterophorus control. 2011, Available from URL: http://www.biosecurity.qld.gov.au/

7. Bhan VM, Kauraw LP, Chile A. Biological suppression of weeds with pathogens, In: Biological suppression of plan diseases, phytoparasitic nematodes and weeds, Project Directorate of Biological Control, Bangalore, India, 1998, 192210.

8. Char MB Nagendran CR Ganesh D. Mealy bug on the roots of parthenium weed. Curr Sci, 1975, 44, 207.

9. Chembolli L, Srinivas CR. Parthenium hysterophorus: A wide angle view. Indian J Dermatol Venereol Leprol, 2007, 73, 296-306.

10. Chippendale JF, Panetta FD. The cost of Parthenium hysterophorus weeds to the Queensland cattle industry. Plant Protection Quarterly, 1994, 9, 73-76.

11. CRC. Weed Management Guide: Parthenium hysterophorus Weed (Parthenium hysterophorus). The state of Queensland, Department of Natural Resource and Mines, Queensland Government, Queensland, Australia, 2003.

12. Datta S Saxena DB. Pesticidal properties of parthenin (from Parthenium hysterophorus) and related compounds. Pest Manag Sci, 2001, 57, 95-101.

13. Deshpande KS Deshpande UK Rathore OS. Biological control of Parthenium hysterophorus L. Indian Botanical Report, 1982, 1 , $40-42$. 
14. Devaraja, Narayanaswamy K, Savithri HS, Muniyappa V. Purification of Tomato leaf curl Bangalore virus and production of polyclonal antibodies. Curr Sci, 2005, 89, 181183.

15. Dhawan SR Gupta SK. Spermoplane mycoflora of Parthenium hysterophorus L. and its weed control potential. Adv Plant Sci, 1997, 10, 95-101.

16. Dhileepan K. Effectiveness of introduced biocontrol insects on the weed Parthenium hysterophorus (Asteraceae) in Australia. Bull Entomol Res, 2001, 91, 167-176.

17. Evans HC Ellison CA. Classical biological control of weeds with microorganisms: past, present, prospects. Asp Appl Biol, 1990, 24, 39-49.

18. Fessehaie R, Chichayibelu M, Giorgis MH. Spread and ecological consequences of Parthenium hysterophorus in Ethiopia. Appl Environ Microbiol, 2005, 6, 11-21.

19. Gaikwad CB, Kasture MC, Lambade BM. Evaluation of herbicides for control of Parthenium bysterophorus in waste land. Indian J Weed Sci, 2008, 40, 79-81.

20. Griffiths MW Mcfadyen RE. Biology and host specificity of Platphalonidia mystica (Lep. Cochylidae) introduced into Queensland to biologically control Parthenium bysterophorus (Asteraceae). Entomophaga, 1993, 38, 131-137.

21. Gunaseelan NV Impact of anaerobic digestion on inhibition potential of Parthenium hysterophorus solids. Biomass Bioenergy, 1998, 14, 179-184.

22. Jai K, Jaggi D, Paul MS. Alelopathicc effect of selected weeds on biochemical activity of Parthenium bysterophorus. Curr Res J Biol Sci, 2010, 2, 238-240.

23. Javaid A, Adrees H. Parthenium hysterophorus management by cultural filtrates of phytopathogenic fungi. Nat Prod Res, 2009, 23, 1541-1551.

24. Javaid A, Anjum T, Bajwa R. Biological Control of Parthenium bysterophorus II: Allelopathic effect of Desmostachya bipinnata on distribution and early seedling growth of Parthenium bysterophorus L. Int J Biol Biotechnol, 2005, 2, 459-463.

25. Javaid A, Shafique S, Shafique S. Management of Parthenium bysterophorus (Asteraceae) by Withania somnifera (Solanaceae). Nat Prod Res, 2011, 25, 407-16.

26. Javaid A. Efficacy of some chemical herbicides against Parthenium hysterophorus L. Pakistan J Weed Sci Res, 2007, 13, 93-98.

27. Jayanth KP. Introduction and establishment of Zygogramma bicolorata on Parthenium hysterophorus at Bangalore, India. Curr Sci, 1987, 56, 310-311.

28. Jeyalakshmi C, Doraisamy S, Paridasan VV. Lasidiplodia theobromae: a potential pathogen of Parthenium hysterophorus Linnaeus. In: Proceedings of Second International Conference on Parthenium bysterophorus Management held at Bangalore (Karnataka), 2005, 271-272.

29. Joshi S, Mahadevappa M. Cassia sericea S. to fight Parthenium bysterophorus L. Curr Sci, 1986, 55, 261-262.

30. Kandasamy OS, Sankaran S. Biological suppression of Parthenium bysterophorus weed using competitive crops and plants. In: Proceeding of the 1 st International Conference on Parthenium hysterophorus Management, University of Agricultural Sciences, Dharwad, India, 1997, 33-36

31. Kathiresan RM, Gnanavel I, Anbhazhagan R, Padmapriya SP, Vijayalakshmi NK, Arulchezhian MP. Ecology and control of Parthenium bysterophorus invasion in command area. In: Proceedings of the $2^{\text {nd }}$ International Conference on Parthenium bysterophorus Management, December 5-7, 2005, Bangalore, India, 77-80.
32. Kaur M, Aggarwal NK, Kumar V, Dhiman R. Effects and Management of Parthenium hysterophorus: A Weed of Global Significance. Int Sch Res Notices, 2014, 2014, 1-12.

33. Kauraw LP, Chile A, Bhan VM. Evaluation of Fusarium pallidoroseum (Cooke) Sacc. for the biocontrol of Parthenium bysterophorus L. In: Proceedings of First International Conference on Parthenium hysterophorus Management, 6-8 October (1997) Dharwad, India, 70-74.

34. Khan H, Khan BM, Hassan G Khan MA. Chemical control of Parthenium bysterophorus L. at different growth stages in noncropped area. Pakistan J Bot, 2012, 44, 1721-1726.

35. Khan N, O'Donnell C, Shabbir A, Adkins SW. Competitive displacement of Parthenium hysterophorus weed with beneficial native and introduced pastures plants in central Queensland, Australia. In: Seventeenth Australian weeds conference. Christchurch Convention Centre, Christchurch, New Zealand. 26-30 September 2010, 131-134

36. Khosla SN, Sobti SN Effective control of Parthenium bysterophorus L. Pesticides, 1981, 15, 18-19.

37. Kishun R, Chad R. New collateral hosts for Pseudomonas solanacearum. Indian J Mycol Plant Patho, 1988, 17, 237.

38. Knox J. An investigation on suppressing capabilities of some allelopathic plants against Parthenium bysterophorus L. [Ph.D. thesis], Dr. B. R. Ambedkar University, Agra, India, 2008.

39. Kumar CV, Rao AS. Two new leaf spot diseases. Indian Phytopath, 1977, 30, 118-120.

40. Kumar S, Jayaraj S Muthukrishanan TS. Natural enemies of Parthenium bysterophorus Linn. J Entomol Res, 1979, 3, 32-35.

41. Lonkar A, Mitchell JC, Calnan CD. Contact dermatitis from Parthenium hysterophorus. Trans St Johns Hosp Dermatol Soc, 1974, 60, 43-53.

42. Maheshwari JK. Parthenium bysterophorus. Curr Sci, 1966, 35, 181-183.

43. Masum SM, Mirza Hasanuzzaman, Ali MH. Threats of Parthenium hysterophorus on agro eco systems and its management: a review. Int J Agri Crop Sci, 2013, 6, 684-697.

44. Mcconnachie AJ, Strathie LW, Mersie W, Gebrehiwot L, Zewdie K, Abdurehim A, Abrha B, Araya T, Asaregew F, Assefa F, Gebre-Tsadik R, Nigatu L, Tadesse B Tana T Current and potential geographical distribution of the invasive plant Parthenium bysterophorus (Asteraceae) in eastern and southern Africa. Weed Res, 2011, 51, 71-84.

45. Mcfadyen RE Parthenium hysterophorus weed and human health in Queensland. Aust Fam Physician, 1995, 24, 1455-9.

46. Mishra JS, Bhan VM. Efficacy of sulfonyl urea herbicides against Parthenium bysterophorus. Indian J Weed Sci, 1994, 26, 104-108.

47. Mitchell JC, Calnan CD. Scourge of India: Parthenium hysterophorus dermatitis. Int J Dermatol, 1978, 17, 303-4.

48. Narasimhan TR, Ananth M, Swamy MN, Babu MR, Mangala A Rao PV. Toxicity of Parthenium hysterophorus L. to cattle and buffaloes. Experientia, 1977, 33, 1358-1359.

49. Pandey AK, Luka BM, Hasija SK, Rajak RC. Pathogenicity of some fungi to Parthenium hysterophorus an obnoxious weed in Madhya Pradesh. J Biol Contr, 1991, 5, 113-115.

50. Pandey AK, Mishra J, Hasija SK. Effect of inoculum on mycoherbicidal potential of Sclerotium rolfsii against Parthenium bysterophorus. J Mycol Plant Pathol, 1998, 28, 284-287.

51. Pandey AK, Mishra J, Rajak RC Hasija SK. Potential of indigenous strains of Sclerotium rolfsii Sacc. for the management of Parthenium bysterophorus L: A serious threat to biodiversity in India. In: Herbal Medicines, Biodiversity and 
Conservation Strategies (Eds. Rajak R.C. and Rai M.K.) International Book Distributors, Dehradun, 1996, 104-138.

52. Puttaswamy, Deviah M, Rangaswamy MR. A new host record of the vegetable mite, Tetrancychus cucurbitae Rahaman and Sapra. Curr Sci, 1976, 46, 15-16.

53. Raj SK, Khan MS, Snehi SK, Kumar S, Mall S, Rao GP. First report of phytoplasma 'Candidatus phytoplasma asteris' (16SrI) from Parthenium bysterophorus L. showing symptoms of virescence and witches'-broom in India. Australas. Plant Dis Notes, 2002, 3, 44-45.

54. Rajak RC, Farakya S, Hasija SK, Pandey AK. Fungi associated with congress weed. Proc Natl Acad Sci, 1990, 60, 165-168.

55. Rajulu SG, Gowri N, Perumal NS. Biological control of the pernicious weed Parthenium hysterophorus Linn. Curr Sci, 1976, 45, 624-625.

56. Ramamoorthy M, Uthayakuar B, Rajapandian JS, Muthusankara narayanan A Integrated weed management for Parthenium hysterophorus. The Hindu, Online Edition of India's National News Paper, Dec.4, 2004, Available from URL.

http://www.hindu.com/seta/2003/12/04/stories/200312040 0101700.htm.

57. Rao AP, Rao AS. New fungal diseases of some weeds. Indian Botanical Reporter, 1987, 6, 38.

58. Ray P, Gour HN. Integrated management of Parthenium hysterophorus L. (Asteraceae): a weed of worldwide significance. Indian J Mycol Plant Pathol, 2012, 5, 605-632.

59. Reddy KN, Bryson CT, Burke IC. Ragweed Parthenium bysterophorus control with preemergence and Posemergence Herbicides. Weed Technol, 2007, 21, 982-986.

60. Sarkate MB, Pawar VM. Establishment of Mexican beetle (Zygogramma bicolorata) Pallister in biological suppression of Parthenium bysterophorus in Maharashtra, In: Proceedings of Second International Conference on Parthenium hysterophorus Management held at Bangalore (Karnataka), 5-7 December 2005, (Eds. PRASAD et al.), 2005, 120-122.

61. Seema Patel. Harmful and beneficial aspects of Parthenium bysterophorus: an update. 3Biotech, 2011, 1, 1-9.

62. Shabbir A, Bajwa R. Parthenium bysterophorus- Spread and status on its management in Pakistan, In: Proceedings of Second International Conference on Parthenium bysterophorus Management held at Bangalore (Karnataka) 5-7 December 2005, (Eds. PRASAD et al.) 28-35.

63. Sharma VK, verma P, Maharaja K. Parthenium bysterophorus dermatitis. Photochem Photobiol Sci, 2013, 12, 85-94.

64. Singh BR, Singh AK. Occurrence of two MLO diseases on congress grass and their management in Uttar Pradesh. Int J Trop Plant Dis, 1998, 16, 55-59.

65. Singh NP. Potential biological control of Parthenium bysterophorus L. Curr Sci, 1983, 52, 644

66. Singh PK, Anil VP, Singh D, Gogoi AK. On farm evaluation of herbicides for the control of Parthenium hysterophorus and Ipomea species under non-crop situation. Proceedings of the National Seminar on Alien Invasive Weeds in India, Jorhat, India, 2003, 88-90.

67. Singh S, Yadav A, Balyan RS, Malik RK, Singh M. Control of ragweed Parthenium hysterophorus and associated weeds. Weed Technol, 2004, 18, 658-664.

68. Srikanth J, Reddy GV, Mallikarjunappa, Kumar P. Records of Orthezia insignis (Homoptera: Ortheziidae) on Parthenium hysterophorus Linnaeus. Entomon, 1988, 13, 185- 186.
69. Sushilkumar, Saraswat VN. Integrated management: The only solution to suppress Parthenium bysterophorus In: Alien Weeds in Moist Tropical Zones: Banes and Benefits" (Eds. Sankaran K.V., Murphy S.T. and Evans H.C.) Workshop Proceedings, 2 4 November, 1999, Kerala, India, Kerala Forest Research Institute, India and CABI Bioscience, UK Centre (Ascot), UK, 2001, 150-168.

70. Sushilkumar. Biological control of Parthenium bysterophorus in India: status and prospects. Indian J Weed Sci, 2009, 41, 1-18.

71. Sushilkumar. Survey of insect and non-insect fauna of weeds in Jabalpur and adjoining area. In: Annual report (1997- 98). National Research Centre for Weed Science, Jabalpur, India, 1998, 37.

72. Swain D, Pandey P, Paroha S, Singh M, Yaduraju NT. Allelopathic effect of Amaranthus spinosus on Parthenium bysterophorus. Ann Plant Protect Sci, 2004, 12, 409-413.

73. Tamado T, Ohlander L, Milberg P. Interference by the weed Parthenium bysterophorus $\mathrm{L}$. with grain sorghum: influence of weed density and duration of competition. Int J Pest Manage, 2002, 48, 183-188.

74. Taxon: Parthenium bysterophorus L. Germplasm Resources Information Network. United States Department of Agriculture. 2008-07-18. Retrieved 2010-10-29.

75. Thangavelu K. Report of Leptocentrus taurus Fabricious Membracidae: Homoptera) feeding on Parthenium bysterophoru. Linn. Entomon, 1980, 5, 355-356.

76. Thapar R, Singh NB. Allelopathic effects of Amaranthus viridis on Parthenium hysterophorus. J Indian Bot Soc, 2003, 82, 93-96.

77. Thontadarya TS, Hiremath IG. Weed as alternate host plant of spotted bollworms (Earias spp.) of cotton. All India Weeds Science Conference, Coimbatore, 1978, 41.

78. Van Der Laan M, Reinhardt CF, Belz RG, Truter WF, Foxcroft LC, Hurl EK. Interference potential of the perennial grasses Eragrostis curvula, Panicum maximum and Digitaria eriantha with Parthenium bysterophorus. Tropic Grassl, 2008, 42, 88-95.

79. Vitonde S, Thengane RJ, Ghole VS. Allelopathic effects of Cassia tora and Cassia uniflora on Parthenium hysterophorous L. J Med Plants Res, 2014, 8, 194-196.

80. Wahab S. Management of Parthenium hysterophorus through an integrated approach initiatives, achievements and research opportunities in India. Proceeding of the $2^{\text {nd }}$ International Conference on Parthenium hysterophorus Management, December 5-7, 2005, University of Agricultureal Science, Bangalore, India, 2005, 55-59.

81. Warshaw EM, Zug KA. Sesquiterpene lactone allergy. Am J Contact Dermat, 1996, 7, 1-23.

82. Watson AK, Wymore LA. Identifying limiting factors in the biocontrol of weeds. In: New Directions in Biological Control: Alternatives for Suppressing Agricultural Pests and Diseases, Academic Press, New York, NY, USA. 1990, 305-316.

83. Yadollahi P, Abad AB, Khaje, Asgharipour MR, Amiri A Effect of intercropping on weed control in sustainable agriculture. Intl J Agri Crop Sci, 2014, 7, 683-686.

\section{Cite this article as:}

Jayaramaiah R., Balenahalii N. Ramesh, B. T. Krishnaprasad, Sunil Kumar R., Pramodh G., Ramkumar C., Sheshadri T. Harmful effects of Parthenium hysterophorus and management through different approaches - A review. Annals of Plant Sciences 6.5 (2017) pp. 1614 1621

DOI: http://dx.doi.org/10.21746/aps.2017.05.002 